\title{
New Parliament, New Politics in Scotland
}

BY JAMES MITCHELL

The promise of 'new politics' following the establishment of the Scottish Parliament had been part of the rhetoric of the Scottish home rule movement. The nature of new politics was never precisely defined but some of its features can be discerned from statements made by senior figures in the campaign for a Scottish parliament, the publications of the campaign groups and the 'Scotland Forward' umbrella organisation which campaigned for a tax-varying Parliament during the 1997 referendum. Three aspects stand out from this rhetoric: new institutions, new processes and a new political culture. The extent to which politics in Scotland has been changed and the degree of novelty that has emerged is considered in this article. It is argued that while there has been substantial change in the institutions, and to some extent in the policy making processes, there has been little evidence of a change in Scotland's political culture.

Various organisations were involved in the long campaign for a Scottish Parliament. Since its establishment, a new battle has been taking place amongst these bodies about which should be given most credit for the success of the campaign. Here, however, that is less important than which organisations used the rhetoric of new politics in their campaign. While the Scottish National Party (SNP) can claim to have played an important part in the establishment of the Parliament, it did not present its case in the same terms as other organisations. Indeed, the SNP always maintained that while devolution would bring about an improvement, a truly new Scotland would have to await independence. In the 1990s, the Constitutional Convention, a cross-party body comprising Labour, the Liberal Democrats, trade unions, churches, local authorities and other civic organisations, was much more closely associated with the rhetoric of new politics. This rhetoric was inevitably pronounced within New Labour.

The implicit assumption amongst home rulers was that new institutions would create new procedures which would break Scotland free of old-style, elitist, confrontational politics centred on the House of Commons. It was either assumed that there was an underlying consensus in Scottish politics which was frustrated by old institutions and practices or that new institutions and practices could create a new consensual political culture. Either way, the relationship between political institutions, procedures and political culture was assumed to be positive and direct. In reality, the new institutions and, more especially, the new

(C) Hansard Society for Parliamentary Government 2000

Parliamentary Affairs (2000), 53, 605-621 
procedures, have proved incapable of overcoming adversarial politics and incapable of achieving the high ideals of many home rulers. In large measure, the expectations of many home rulers were unrealistic, based on underestimating the extent of political differences in Scotland and overestimating the power of formal institutions to affect processes and political behaviour.

The key change has been the creation of the 129-member Scottish Parliament. Its electoral system was a break with the past, though the first-past-the-post element and the boundaries of constituencies were based on those for the House of Commons. The additional members element provided novelty and a degree of proportionality otherwise unknown in Scottish electoral politics. The procedures of the Parliament also appear to be different from those of the Commons, though less so than many of its members and some home rulers seem to think. The ideals of home rulers to achieve a more open, participatory democracy are also evident in some of the procedures which have been adopted. The intention to give the committees a greater role in policy-making and to provide backbench members with a significant role featured in debates leading up to the establishment of the Parliament. Only limited success can be claimed in achieving these.

\section{New institutions}

The creation of a new Parliament was in itself novel. What was not new was acknowledgement that Scotland was different. That had long been established, and distinct Scottish institutions has existed throughout the period of union. However, supporters of a Scottish Parliament envisaged a new type of Parliament. While the precise details may have been unclear, it was intended that it would not be modelled on Parliament at Westminster. However, the consequence has been that Westminster, and the House of Commons in particular, continues to be a significant influence. In their determination to be different from it, members of the Scottish Parliament have ensured that it has dominated the development of the Scottish Parliament. The Commons has acted as a negative template for the home rulers. Accordingly, much of the preparatory work within the Constitutional Convention prior to the 1997 general election drew consciously on models from abroad, if erratically and not always fully understood. In this respect, the Scottish home rule movement had been Europeanised. Institutionally, two features of the proposals were novel: the electoral system and the internal workings of the Parliament.

The main critique of the arrangements for governing Scotland prior to devolution had focussed on the Scottish Office. As part of UK central government, Scottish Office ministers were appointed by the Prime Minister. In 1988, a Claim of Right was drawn up by a Constitutional Steering Committee, set up by the Campaign for a Scottish Assembly. ${ }^{1}$ It criticised the Scottish Office, maintaining that it could not possibly 
provide Scotland with distinctive government according to Scottish wishes. The need to rejuvenate Scottish democracy, to ensure that the executive was accountable to a Scottish legislature, was a key theme in its critique of then existing arrangements. Criticisms of the lack of time spent in the House of Commons on Scottish business and the lack of accountability developed into a need for a more assertive legislature. Not only did home rulers want a Scottish Parliament, they wanted the legislature to assert itself in its relations with the executive. However, many home rulers and advocates of 'new politics' have tended to focus on the Parliament as a whole, often ignoring the distinction between it and the Scottish Executive. The emphasis has been on access to the Parliament as a whole rather than access to power.

THE ELECTORAL SYSTEM AND REPRESENTATION. The most significant institutional innovation proposed by the Convention was in the electoral system. At least rhetorically, this related to the need for a new political culture. The Convention prided itself on its wide base of support and particularly the involvement of two of Scotland's main political parties. The consensual nature of its activities, it was felt, should be a model for the Parliament itself. Significantly, some of the strongest support for this came from within the Labour Party, particularly amongst radical home rulers. Scotland had traditionally had low levels of women's participation in politics even by the wider standards of the UK. Women's groups, particularly in the trade unions and the Labour Party, argued that the new Parliament offered an opportunity to right an historic wrong. In addition, a desire to provide greater proportionality in the electoral system emerged strongly within the Convention. Differences between Labour and the Liberal Democrats on how to achieve 50:50 men-women representation existed but, in principle, both parties supported this goal.

The evolution of support for an alternative form of representation began with a statement of principles set out by the Convention: that it produces results in which the number of seats for various parties is broadly related to the number of votes cast for them; that it ensures, or at least takes effective positive action to bring about equal representation of men and women and encourages fair representation of ethnic and other minorities; that it preserves a link between the member and his/her constituency; that it is as simple as possible to understand; that it ensures adequate representation of less populous areas; and that the system is designed to place the greatest possible power in the hands of the electorate. ${ }^{2}$

It would have been impossible to find an electoral system which achieved all of these objectives. Compromise was inevitable and some principles suffered more than others. After the 1992 general election, a small commission was appointed by the Convention with the task of dealing with unresolved issues, including the electoral system. It pro- 
posed an Additional Member System, with each voter having two votes: one for a constituency MP based on the existing Westminster constituencies, another vote for a party. The constituency votes would therefore provide 72 Members of the Scottish Parliament (MSPs). In the event, the Liberal Democrats succeeded in gaining two separate constituencies in the Scottish Parliament for both Orkney and Shetland instead of just one, and the number of additional members was set at 56 , based on the old European Parliamentary constituencies.

The outcome of the first election in May 1999 was that no party had an overall majority, though Labour had a convincing majority amongst constituency members. In other words, had the old first-past-the-post system been used on its own, Labour would have had an overall majority of 20 in a Parliament of 73 instead of having 56 seats in a Parliament of 129 . Whether this amounts to a form of new politics depends on whether the electoral system with its degree of proportionality continues in being in the future, and whether the proportion of women changes. The electoral system is bound to change in some respects if only because the constituency section is based on House of Commons constituencies and the list members are elected on the basis of European constituencies. Scotland's share of Commons seats is set to fall after the next boundary review under the terms of the devolution legislation, with consequences for how the Scottish Parliament is elected. The European constituencies used for the regional list vote have disappeared with the new voting system for the European Parliament.

The electoral system and gender representation (see below) suggest that the establishment of the Parliament does indeed mark a major shift in Scottish politics, justifying the claims of introducing new politics. However, that must be set against the certainty that the electoral arrangements will change and less proportionality may be introduced. In addition, the motives for introducing a new electoral system can be questioned. While its introduction was dressed up in the language of new politics and consensus, some very old adversarial politics were evident. Under first-past-the-post there was always the possibility that the SNP might one day achieve an overall majority. From Labour's point of view, a system that deprived the SNP of winning power in Scotland was appealing, even if the cost was that Labour would also be unable to form a government on its own. This was acknowledged by Labour's then Scottish general secretary during the 1997 general election campaign. ${ }^{3}$ In the event, governing in coalition with the Liberal Democrats has been relatively painless for Labour. The joint statement by the leaders of the Scottish Labour Party and the Scottish Liberal Democrats, setting out a programme for government, contains little, if anything, that Labour would not have introduced. Even on the contentious issue of student fees a compromise was found. Labour spin doctors even found it possible to explain some executive failings by blaming the Liberal Democrats. 
Of the six objectives set out by the Convention for a new electoral system, many have been achieved: greater proportionality has been introduced; equality of representation of men and women may not have been achieved but there has been a substantial improvement on past experience; there is still a link between the member and his/her constituency for the 73 constituency members; and the electoral system is fairly simple and easily understood. Labour introduced a system of twinning constituencies for the selection of candidates in order to ensure that it achieved 50:50 men-women representation. This resulted in Labour having an equal number of men and women in the Parliament. Fourteen men and only three women were returned for the Liberal Democrats, 19 men and 16 women for the SNP, 15 men and three women for the Conservatives, plus three other men.

However, the prospect of future change in the electoral system may undermine some of these achievements, including the degree of proportionality. Some of the objectives have not been achieved. Ethnic minorities remain unrepresented. None of Scotland's parties placed candidates from ethnic minorities in seats that could be won. Disputes continue about whether list MSPs can have constituency offices. Despite early assurances that all would be treated alike, constituency MSPS have been given greater resources and list MSPs have been told that they ought not to have constituency offices. Far from new politics, this reflects the fact that Labour and the Liberal Democrats, with their representation coming overwhelmingly from the constituencies, want to deprive the Conservatives and SNP, deriving all and most of their MSPs respectively from the lists, of resources.

During the referendum campaign it was frequently asserted, especially by home rulers campaigning in the Borders and in the Highlands and Islands, that the AMS list system ensured that these less populated areas would be better represented. In fact, the proportion of MSPs coming from these areas is broadly in line with the territorial representation of Scottish MPs in the House of Commons (see Table). Westminster constituencies already take account of 'special geographical consideration' and sparsely populated areas already did well prior to devolution. ${ }^{4}$

The electoral system did allow for new regionally-based parties, or parties that were weak across Scotland but had pockets of support, to

Territorial Representation of Scotland in Westminster and Edinburgh

$\begin{array}{lcc} & \text { Westminster Seats } & \begin{array}{c}\text { Edinburgh Seats } \\ \text { (FPTP + top-up) }\end{array} \\ \text { Highlands and Islands } & (\text { FPTP) } & 15(11.6 \%) \\ \text { North East } & 7(9.7 \%) & 16(12.4 \%) \\ \text { Mid Scotland and Fife } & 9(12.5 \%) & 16(12.4 \%) \\ \text { West of Scotland } & 9(12.5 \%) & 16(12.4 \%) \\ \text { Glasgow } & 9(12.5 \%) & 17(13.2 \%) \\ \text { Central Scotland } & 10(13.9 \%) & 17(13.2 \%) \\ \text { Lothians } & 10(13.9 \%) & 16(12.4 \%) \\ \text { South of Scotland } & 9(12.5 \%) & 16(12.4 \%)\end{array}$


emerge. The Scottish Socialist Party thus managed to win a seat in Glasgow and the Greens won a seat in Lothians under the regional list. Neither party would have won a seat otherwise. However, the Highlands and Islands Alliance, fighting only regional list seats in the Highlands, failed to make a breakthrough.

INTERNAL WORKINGS OF THE PARLIAMENT. Little work had been done by the Convention on the internal workings of the Parliament. The main work was done after the referendum in an all-party Consultative Steering Group set up by the government. Its most significant feature was that, while it included a number of politicians, it included nobody who was in any way an authority on legislatures or parliamentary procedures. This was reflected in its report. Its working assumption appears to have been that the Parliament would be important in policymaking, ignoring all the evidence that it is the executive which dominates policy-making. There is no mention of political parties in the report. The Consultative Steering Group adopted four 'key principles' to guide its work: the Scottish Parliament should embody and reflect the sharing of power between the people of Scotland, the legislators and the Scottish Executive; the Scottish Executive should be accountable to the Scottish Parliament and the Parliament and Executive should be accountable to the people of Scotland; the Scottish Parliament should be accessible, open, responsive and develop procedures which make possible a participative approach to the development, consideration and scrutiny of policy and legislation; the Scottish Parliament in its operation and its appointments should recognise the need to promote equal opportunities for all. ${ }^{5}$ These were summarised as sharing power, accountability and participation. The White Paper on devolution published in July 1997 had envisaged parliamentary committees with an important role and this was endorsed by the Consultative Steering Group. Committees would initiate legislation, scrutinise and amend the Scottish Executive's proposals and have wide-ranging investigative powers.

The implication was that more power would be held in the legislature amongst ordinary MSPs in relation to the Executive than might have been expected from a system modelled on the House of Commons. However, the prospect that the Executive would willingly allow its control of the policy-making agenda to be lost to the Parliament as a whole was never realistic. This might happen as a consequence of the lack of an overall majority for the governing party and would have serious consequences for the effective operation of business. In other words, a situation in which a governing party lost control of its legislative agenda was not only something which the Consultative Steering Group failed to address but appears to be one which it wanted. There was simply no appreciation of the importance of stability or the reality of party whips in its thinking. 
Some of the committees have cut out a role for themselves, though none are likely to initiate legislation successfully without the consent of the Executive. Disillusionment with the committees has been expressed by John McAllion, leading home rule campaigner and Labour MSP. Writing in October 1999, he noted that the committees were supposed to embody new politics - 'practical, principled and non-partisan ... political idealism made flesh and blood' - but noted that the budgets available to them limited their impact. ${ }^{6}$ With many MSPs serving on two of the 16 committees, it was proving difficult to find the time to devote sufficient attention to issues. The prospect of a reduced number of MSPs, as discussed above, would only exacerbate an already difficult situation. The priority given to the scrutiny of the Executive's legislative programme meant that much committee time has been tied up with government business, thus limiting opportunities for backbench initiatives. There is broad agreement across the parties that the degree of party-political point scoring is far less in the committees than on the floor of the Parliament, but McAllion has admitted that party groups had begun to form in them, frustrating another element of new politics. An example of this has been the Finance Committee's decision not to investigate the Barnett formula (used in the distribution of public funds within the United Kingdom). This thorny issue is one that New Labour in London would not wish to open up and evidence suggests that, in this case, it is the Executive that has control of the Finance Committee rather than the other way around.

Mike Russell, Business Manager for the SNP in the Parliament, has suggested possible reforms that might go some way towards addressing problems faced by the committees, for example that there should either be a reduction in the number of committees or the number of MSPs on committees and committees might include non-voting members who are not MSPs. The last would allow all parties to make amends for failing to adopt candidates from ethnic minorities though it raises other issues of representation. Complaints by supporters of new politics that the media spend insufficient time covering the committees' work might prove counter-productive. ${ }^{7}$ The absence of the media may allow for less confrontational politics.

CIVIC FORUM AND CIVIC SOCIETY. Following much of the rhetoric surrounding the Constitutional Convention, the Consultative Steering Group made much of the role of 'civic society' and the need for a more open political system. It supported the idea of a Civic Forum which would be 'facilitative, recognise the plurality of voices and groups and take an active role in ensuring the effective involvement of groups traditionally excluded from the decision-making process'.$^{8}$ It also recommended other institutions and processes for encouraging greater citizen participation, including social partnerships, consensus conferences, citizens' juries, deliberative opinion polling, citizens' panels and 
public petitions. The Scottish Executive has given its support in principle to the idea of a Civic Forum and agreed to provide modest funding.

The precise role of a Civic Forum remains unclear. Kenyon Wright, who had served as a member of the Consultative Steering Group, argued that a Civic Forum might help on controversial decisions. He cited the debate about whether a children's heart surgery unit should be based in Glasgow or Edinburgh as an example. This seems exactly the kind of issue about which a Civic Forum would be incapable of making a decision because its membership would be unlikely to have the expert knowledge or impartiality required. ${ }^{9}$ His argument that the Forum could have set up a 'citizens' jury, composed of ordinary people with some kind of expertise' is fanciful at best. The fact that the Executive refused to publish an expert's report on the location of the unit makes it unlikely that this would be the kind of issue that would be devolved to a Forum unless the Executive saw it as a way of avoiding a difficult and divisive matter. In other words, the Forum might take the form of the 'devolution of penury' from the devolved Parliament. Such proposals may be motivated by a desire to increase participation but are more likely to blur lines of accountability. This typifies a failure of supporters of new politics to confront the possibility that two ideals might be in conflict, in this case accountability and participation.

A more reasonable issue for a Forum to discuss was proposed by Bill Spiers, general secretary of the Scottish Trades Union Congress. In evidence to the Parliament's Procedures Committee, he argued that the 'perennial, difficult and important issue' of drugs, with which every political party had difficulty, might best be debated in a Civic Forum. That would then allow the parties to pick up any proposals that emerged from it. ${ }^{10}$ Its role would be to raise difficult issues on to the political agenda that would otherwise not be raised. It would not necessarily mean that it would deliver a ready made policy to the Parliament but might debate difficult issues without having to vote on recommendations.

The composition of a Forum has also caused difficulty. Its supporters are caught between their long-term commitment to a directly-elected Parliament as the legitimate voice of the Scottish people and a desire to encourage wider participation. Supporters of the idea appear to come from pressure groups and refer to organised opinion. A grouping calling itself Changing the Culture of our Politics Group put forward proposals in meetings with the Scottish First Minister and the Parliament's Procedures Committee. The representation to the Committee consisted of Alice Brown, an academic member of the Consultative Steering Group who had been active within the Constitutional Convention and representatives from the main teaching union, the Scottish Trades Union Congress and the Scottish Council of Voluntary Organisations. A Labour member of the Procedures Committee raised the possibility of the Forum becoming the vehicle for some particular body or individual. 
The claimed authority of the Changing the Culture of our Politics Group was derived from the organisations it represents and it could have been criticised for representing only a section of Scottish civil society. Arguments used by home rulers against the system of government which predated devolution included the need to move away from a system in which only organised interests had access to the Scottish Office, keeping unorganised opinion outside. What the Group appeared to be proposing was that elements of the old system, albeit with different groups having insider status, should be reconstituted.

In its evidence to the Procedures Committee, it became clear that there was much confusion on whether political parties could affiliate to a nascent Civic Forum that had been formed. A spokesman for the SNP announced that the SNP Parliamentary Group had affiliated and urged other groups to do likewise. This provoked surprise and opposition to party political affiliation from members of the Changing the Culture of our Politics Group and other MSPs. The notion of a Civic Forum appears to have been an idea that had not been thoroughly considered by its advocates in the Consultative Steering Group and beyond. Neither its membership nor its remit had been given serious attention, far less from where it would derive its authority and how it would relate to the Scottish Parliament or Executive. Some advocates of new politics sound as if they are outsider groups seeking insider status, while others sound as if they are advocating a radical overhaul of the political system.

\section{New processes}

PARTICIPATION. While the emphasis on 'new' emerged most powerfully under Tony Blair's leadership of the party, it had appeared before in debates on constitutional change within the Labour Party. John Smith, its late leader, argued in a lecture in October 1992 that three factors had convinced him that there was need for reform. The first was the experience of centralisation under the Conservatives. The second was the European dimension. The third was a 'discreet but significant sociological shift' from 'traditional perceptions of ourselves as subjects to a more modern view of ourselves as citizens' ${ }^{11}$ Notions of subsidiarity were then in vogue and frequent comparisons with experience elsewhere in Europe were cited by home rulers as evidence of new, modern structures of government. The notion of Scots as citizens rather than subjects had played a powerful part in the deliberations of the Constitutional Convention. The founding document stressed the 'sovereignty of the Scottish people' as distinct from the sovereignty of Parliament.

The cry of popular sovereignty was the basis of the Scottish Constitutional Convention. A Claim of Right for Scotland had been signed by almost all participants in the Convention. ${ }^{12}$ It asserted that it was the 'sovereign right of the Scottish people to determine the form of govern- 
ment best suited to their needs'. This challenge to notions of parliamentary sovereignty and of people as subjects of the Crown would have been a revolutionary element in the Convention's thinking had it been more than rhetoric. In the event, the assertion of parliamentary sovereignty in both the devolution White Paper and the devolution legislation undermined the rhetoric of the Claim. ${ }^{13}$ Nonetheless, greater participation and the involvement of active citizens were key themes in the rhetoric of the campaign.

The main problem for supporters of greater participation has been their focus on the Parliament. By focusing on greater participation in its workings they ignore the most important branch of government. The Parliament's importance lies in determining the composition of the Scottish Executive and legitimising the Executive's work. Power lies in attenuated form in the Scottish Parliament. Participation through its organs would go some way to providing it with greater authority but is not necessarily a route to changing public policy. A more direct route to power would focus directly on the Executive. Advocates of new politics have remarkably little to say about this. Acknowledging that the Executive is more powerful than the Parliament does not mean that the Parliament is powerless but it does raise questions about the nature of meaningful participation.

LOBbying. With the closing years of Conservative rule at Westminster as the background to the emergence of the Scottish Parliament, it was inevitable that new politics would include the repudiation of 'sleaze'. The problem for home rulers was finding a method of controlling access to professional lobbyists while opening the Parliament up to 'civic Scotland'. In Autumn 1999, the issue of lobbying arose controversially when the Observer newspaper reported that Beattie Media, a new lobbying company which employed the son of the Secretary of State for Scotland, had approached a potential client promising it could use personal contacts to get access to senior Scottish (Labour) politicians. There were three important aspects to the row. The first was that it highlighted an ongoing turf war between Donald Dewar as First Secretary in the Scottish Executive and John Reid, Secretary of State for Scotland in London. The second was to highlight what many commentators, including senior figures in the Constitutional Convention, regarded as the need for tighter control of lobbying. The third was the manner in which the issue became embroiled in party political competition within the Parliament, with the SNP exploiting Labour's difficulties in much the same way that Labour had exploited Conservative difficulties in the closing months of the Major government. In each respect, 'lobbygate' had the hallmarks of old politics.

Kenyon Wright, of the Constitutional Convention, insisted on three courses of action in order to protect the ideals of new politics. The Parliament's Standards Committee must meet in public to deal with the 
allegations of impropriety, otherwise it would be 'deeply damaging, possibly fatal, to the "new political culture" to which we all signed up'. Second, all 'mercenary lobbying firms' should be made 'redundant'. Third, it was necessary to put in place the civic institutions that would monitor the implementation of the Consultative Steering Group principles of power-sharing, accountability and participation. ${ }^{14} \mathrm{~A}$ problem that had arisen early on and encouraged the development of new lobbying firms in Edinburgh was that many groups and individuals found the procedures of the Parliament daunting and complex. The ways in which MSPs, committees and the Executive could be lobbied legitimately was unclear, especially those with little or no experience. In some respects, this was extraordinary. It was not as if the Parliament created an entirely new set of institutions. The Scottish Office had existed from 1885, and groups and individuals in Scotland had long experience of lobbying it. Home rulers were paying the price of exaggerating the novelty of the Scottish Parliament. It involved the establishment of a democratic component to an existing distinctive structure of government in Scotland. Groups and individuals would have to alter their behaviour accordingly rather than assume that they had to start completely afresh. Once more, the failure to distinguish between the Parliament and Executive created unnecessary problems for advocates of new politics.

Nonetheless, there have been problems even for experienced groups in dealing with the new institutions. The promise of more written guides on the way the Parliament works may go some way to providing formal information on how legislation is passed and how groups and individuals can participate more fully. It is unlikely to alter the uneven access that exists when professional lobbyists and experienced groups compete against inexperienced, weakly organised interests. The pressure on committees mentioned above has meant that the intention of encouraging more access and allowing groups to give evidence at different stages in the legislative process has not always been realised. The Justice and Home Affairs Committee, in particular, had an immense amount of work to do in the first year of the Parliament because of its remit, and this pressure has reduced the opportunity it had to take evidence. While some MSPs have argued that there needs to be a reduction in the number of committees in response to pressures outlined above, it has also been suggested that two committees dealing with Justice and Home Affairs might be established to reduce the pressure.

The ideal of increasing participation by allowing groups to present evidence at different stages to committees adds to the pressure that MSPs and committees are under. The prospect of fewer MSPs in a smaller Scottish Parliament could only exacerbate an already difficult situation. The lesson for supporters of new politics is that it carries costs and that the Parliament may not be the best or the only focus for legitimate lobbying. 
MORE OPEN POLICY-MAKING PROCESS. Writing in Scottish Business Insider, Peter Jones offered an alternative interpretation of 'new politics' to that of the 'consensus-seekers'. Those who imagined that new politics would involve politicians being 'nice to each other in a state of blissful happiness, irrespective of party differences' were naïve. The differences between the parties remain profound. New politics, he maintained, involved much greater public involvement and participation in the political and legislative process. Indeed, for him some radical new thinking was required in Scottish politics that might challenge the existing consensus. He cited the Transport Bill, then going through the Scottish Parliament, allowing for tolls to be imposed on the motorway between Edinburgh and Glasgow, as an example of a new idea that required to be given serious consideration. He was critical of old politics, as displayed by the SNP in its 'rush to judgement' that this was a new tax.

According to Jones, old Westminster politics was typified by the government publishing new laws and then defending them against all comers in contrast to the approach of the Scottish Executive which welcomes constructive amendment of its proposals. ${ }^{15}$ Many students of the British policy-making process would, no doubt, challenge this characterisation of how it operates, especially any suggestion that there is a sharp contrast with the operation of the Scottish Executive. Even in this interpretation of new politics, Westminster features heavily as a negative template, though it may be a caricature. Backing down from a proposal following public protest has been evident in a number of cases in London, from genetically modified foods and fox hunting to the hesitation on European policy. Indeed, a sharp criticism of London both under Major and Blair has been the tendency to react to newspaper headlines or focus groups. A potential danger for the Scottish Executive is that it will be accused of confusion and a lack of leadership if it backs away from proposals it brings forward. In the event, this is what happened with its transport policy.

The debate on Clause 28 (prohibiting local authorities from promoting homosexuality) highlighted some of the difficulties many supporters of a more open policy-making process in Scotland have. Advocates of this approach within the home rule movement have generally come from a liberal background. They are people who support the abolition of a clause deemed to encourage homophobia. However, they have had difficulty squaring this with support for greater public participation in the policy-making process. The groundswell of public opinion against changing the law on Clause 28 would have required strong political leadership willing to lead or challenge majority opinion on this. In the event, the amendment of the proposals, in an attempt to appease opponents and supporters, resulted in antagonising both sides.

On a number of occasions the Executive has been criticised for failing to act openly. Scottish journalists complain as bitterly as any others 
that the Scottish Parliament has not brought about open government. One declares that the new Executive was 'failing to enlighten us on its activities': a mixture of inexperienced MSPs, spin doctors and special advisers combine to make the role of the lobby correspondent difficult according to this view. ${ }^{16}$ On the other hand, sections of the media have been criticised for focusing on trivia and attempting to undermine the Scottish Parliament. Common complaints about the calibre of MSPs, often highly personal and abusive, and criticism of an unavoidable early debate on salaries are seen by some supporters of the Parliament as a continuation of the referendum campaign by the losing side. One journalist critical of his peers has called for a 'different and better vocabulary for public discourse'. ${ }^{17}$

\section{New political culture}

Linked to the debate on a new electoral system was a debate on the need for a more consensual style of politics. The contrast with the House of Commons, with its adversarial forum and confrontational style, was frequently alluded to in home rule debates. The experience of the 1997 devolution referendum campaign, when Labour and the SNP cooperated to great advantage, was thought to offer a model of constructive consensual politics. However, while there was agreement between the two parties in this particular campaign there was much that divided them. The reasons why they supported devolution differed: the SNP saw it as a stepping stone to independence, while Labour saw it is a way of consolidating the union. Both could not be right. However, for the purposes of the referendum, they each wanted the same result and could see advantages in cooperating, even if relations were often strained. Further evidence suggests that when the parties perceive cooperation to be mutually advantageous or they have a genuine common goal, then they are willing to join forces. In October 1999, Donald Dewar, Labour First Secretary, and Alex Salmond, SNP leader, shared a platform for the launch of the Scotland in Europe campaign, the pro-euro campaign in Scotland. Once more, the Liberal Democrats were also present in a supporting role to the two key players in Scottish politics, helping to highlight the extent of crossparty support and the apparent marginalisation of the Conservatives in Scottish politics.

While many newspaper columnists and editorials in Scotland have bemoaned the absence of cooperation and the bitterness of exchanges between the two parties and have applauded those occasions when there has been cooperation, they have generally misunderstood the rationale for the limited cooperation that exists. From neither party's point of view does it make sense to cooperate on a wide range of issues even if differences between the parties hardly exist. The nature of the intense electoral competition means that differences are exaggerated and cooperation will only occur in the most unusual circumstances. For 
the most part it makes little sense to Labour and the SNP and no institutional change is likely to alter that.

On a range of matters there are few differences between the two main Scottish parties. The socio-economic support for them is remarkably similar, and other than on the constitutional question they have more similarities than differences. However, the function of these similarities has been to intensify competition rather than create consensus. The two parties are competing for the same vote. Combined with very real differences on constitutional politics, this ensures that the battle between them remains and will continue to be bitter. The stakes are high. It would be as naïve to expect Scottish Labour and the SNP to work cooperatively on the wide range of issues on which they have few differences as for New Labour and the Conservatives in London to do the same.

Scottish newspapers in 1998 reported that Helen Liddell, who had been charged with leading the attack on the SNP at the Scottish Office, had been criticised by her Labour colleagues for indulging in 'Natbashing'. The criticisms were sometimes couched in terms of 'tarnishing new politics' but were more accurately based on a belief that her approach was counter-productive. The boundary between old and new politics is not always clear. It has not been unusual for politicians to criticise their opponents for failing to deliver new politics in fairly robust old-style language. Esther Robertson, a leading figure in the Constitutional Convention, for example, reportedly complained that she had heard Alex Salmond attacking some government announcement. That she was a Labour activist undermined her claims to be acting in defence of new politics. Her criticism might have had greater force had they been directed against her own party. Instead, it sounded like a new way of indulging in old politics. The rhetoric of new politics adds a new weapon to the armoury of traditional adversarial politics.

The main problem for advocates of a more consensual style of politics is that there remain unresolved, perhaps irresolvable, issues in Scottish politics that divide the two main parties. The central question in Scottish politics, contrary to the expectations of supporters of consensual new politics, remains Scotland's constitutional status. In an article in May 1998, Kenyon Wright argued that this issue was 'yesterday's question ... For Scotland, as for Ireland, the old battles about which state we want are becoming increasingly irrelevant in the new Europe, in which the nation state is gradually, but irreversibly losing power-or, better say, sharing power in both directions - with the EU, and with the "regions" and nations within states'. He maintained that in the future historians would write that the real issue of this time was 'will Scotland's Parliament be the pioneer of the new kind of politics that the new era so desperately needs'. ${ }^{18}$ In fact, Scotland's constitutional status is even more central to electoral politics after devolution than it was before. 
Even within the parties making up the Executive there has occasionally been evidence of the robust language associated with old politics. Donald Gorrie, a Liberal Democrat MSP, described Labour as the 'biggest bunch of liars you could meet' when he warned his party against joining the coalition. Within the Labour Party, the rancour evident in exchanges between members of the same party must have disappointed Wright. Differences between the First Minister's Office in Edinburgh and that of the Secretary of State in London have not been in keeping with the ideals of many supporters of new politics. None of this is surprising, nor is it alarming. Much of the adversarial rhetoric is theatrical. The language of Scottish politics is no more violent than in most other liberal democracies. More important, Scotland remains remarkably free from political violence and there is agreement on the process through which further constitutional change can be brought about. This degree of consensus may be a reason for relief, if not celebration. Calls for consensus on Scotland's constitutional status can only be achieved by either the SNP or Labour abandoning support for its preferred constitutional option.

Not everyone who supports the Scottish Parliament wants to find public policy expression for an existing political consensus and many of those who opposed devolution for fear that it would consolidate the existing left of centre political consensus in Scotland now hope that the Parliament might facilitate challenges to this consensus. Most explicit in this respect has been the view that has been emerging strongly from within Scotsman Publications under the editorial direction of Andrew Neil. The Scotsman had been a leading advocate of a Scottish Parliament for over thirty years. It did so partly because it sought a means of ensuring that public policy reflected Scottish opinion. Under Neil, however, the paper has undergone a transformation. Before the referendum, it became critical of devolution but still supported it in principle. Since the referendum, its editorial columns and a number of its columnists have argued that Scotland needs to throw off the existing consensus. A Scotsman editorial following the publication of the Executive's first legislative programme complained that it was too cautious: 'If there is to be a new politics in Scotland, then it must be the politics of fresh thinking, of good ideas celebrated and bad ideas shot down. It must be robust and full of life and invention, not dreary and consensual.' ${ }^{19}$

Whether commentators and politicians argue that new politics should give policy form to an existing consensus or challenge existing agreement depends entirely on the issue and views of those concerned. In large measure, there is a battle over the meaning of new politics with fairly widespread agreement that the Parliament should bring this about but dispute about its precise meaning. Old left-right battles have simply found new expression in terms of a debate, if such it could be called, on new politics. 


\section{Conclusion}

The high hopes that the new Scottish Parliament would usher in a new type of politics have not entirely evaporated, but a growing realisation has emerged in Scottish politics that much remains the same as ever. The most vehement critics of devolution in the past have accepted that it has not been the disaster they predicted, though some maintain that it takes Scotland a step closer to independence. However, amongst proponents of new politics there is some disillusionment. The illusions on which their high hopes were based assumed a simple causal relationship between the establishment of a new Parliament elected by a more proportional system and consensual politics. The reasons for the adversarial nature of Scottish politics have not changed. The very real differences between Labour and the SNP did not disappear because of devolution. The two parties have demonstrated both in the devolution referendum and on the issue of the euro that they are willing to cooperate when it serves their interests. If anything, there is less reason for more cooperation between the SNP and Scottish Labour than between New Labour and the Conservatives. The policy differences between the former are greater than between the latter.

Institutionally, there have been some significant innovations in Scottish politics. The electoral system and the representation of women have changed dramatically. There have been teething problems with the internal workings of the Parliament, but these have not been serious. Changes in the overall size of the Parliament would likely exacerbate these problems, though some proposals for reform emerging from within it may help. Despite, or perhaps because of, efforts to avoid the Westminster model, the Scottish Parliament does resemble the former in important respects. Some features of the Commons that provoke most amazement amongst visitors from outside the United Kingdom are still to be found in Edinburgh. The spectacle of Question Time, a key feature of adversarial politics, remains a central part of the week.

Four major criticisms can be made of at least some advocates of new politics in Scotland. First, they have a crude view of the relationship between institutions, processes and political culture. Second, the focus of much of their attention has been misguided as far as access and openness are concerned. Instead of the focus on the Scottish Parliament, there might have been more benefit in emphasising the Executive. The tendency to conflate the two in the thinking of many advocates of new politics has damaged the causes they espouse. Third, there has been too great an expectation that the Parliament would resolve the issue of Scotland's constitutional status. Related to this is what appears to be an attempt to treat politics as an ideologically vacuous exercise in which agreement can be reached and rational policy-making achieved through new institutions and processes. Despite the fact that greater participation, if meaningful, would introduce even more interests into the 
political arena and thereby create more conflict, supporters of new politics assume that it would somehow reduce conflict. This sums up the final criticism of new politics. It has tended to be a slogan around which all sorts of beliefs, sometimes incompatible, have been hung together.

1 Confusingly, there were two Claims of Right. The first was a document drawn up by the Constitutional Steering Committee set up by the Campaign for a Scottish Assembly, a cross-party group of home rulers which included some SNP members. This set out the case for a Scottish Parliament and proposed that a constitutional convention should be established in order to bring it about. The second was a short statement signed by members of the Constitutional Convention once it was established in March 1989 which declared the sovereignty of the Scottish people.

2 Towards Scotland's Parliament: A Report to the Scottish People, Scottish Constitutional Convention, November 1990, p. 12.

3 At a Labour press conference, BBC Scotland's political editor asked Jack McConnell, Labour Scottish General Secretary: 'Why worry, isn't the electoral system [for the proposed Scottish Parliament] designed to prevent the SNP getting power?' to which McConnell replied, 'Correct.' BBC Radio Scotland, 22.4.97.

4 Information from Charles Pattie.

5 Consultative Steering Group on the Scottish Parliament, Shaping Scotland's Parliament, Edinburgh, The Scottish Office, December 1998, p. 3.

6 McAllion, 'Holyrood's Committees find Journey from Idealism to Reality Hard Going', The Herald, 25.10.99.

7 See Brown's comments as part of the Changing the Culture of our Politics Group, Evidence to Procedures Committee, Scottish Parliament, 1.2.00.

8 Consultative Steering Group, op. cit., p. 7.

9 Scotsman, 4.10.99.

10 Proceedings of the Procedures Committee, Scottish Parliament, 1.2.00.

11 J. Smith, 'Reforming Our Democracy: The First Richard Stewart Memorial Lecture', University of Strathclyde, October 1992.

12 At time when the Claim had been signed it was reported that all participants, including all Scottish Labour MPs, had signed the document. It later transpired that Tam Dalyell MP, an inveterate opponent of devolution had not signed it but Labour had managed to keep this quiet for quite some time.

13 Scotland's Parliament, Cm. 3658, 1997; Scotland Act 1998, Section 28(7).

14 Wright, 'A Critical Week for Democracy', Herald, 5.10.99.

15 Jones, 'Door's Open', Scottish Business Insider, 31.7.99.

16 Rait, 'Open Government? Oh No It Isn't', Scotsman, 9.7.99.

17 Moffat, 'Why Scotland Simply Cannot Go On Sniping', Sunday Herald, 25.7.99.

18 Wright, 'New Parliament - New Politics for a New Era?', Herald, 14.5.98.

19 'The New Politics - Keep It Dull', Scotsman, 17.6.99. 